\title{
DEVELOPMENT STAGE, AGEING AND NATURAL MORTALITY OF ANCHOVY EGGS (Encrasicholina SPECIES) FROM BACAN
}

\author{
Retno Andamari*'. David A. Milton ${ }^{* *}$, Andriko N. Susanto*'
}

\begin{abstract}
In order to study the possible application of the Daily Egg Production Method (DEPM) for estimating anchovy (Encrasicholina spp.) biomass at Bacan. Maluku, we collected a large series of plankton samples. All the anchovy eggs from these samples were staged and then aged according to the criteria of Moser and Ahlstrom (1985). We recognised 9 stages of embryonic development from $1 \mathrm{~h}$ to $15 \mathrm{~h}$. From these data we estimated that anchovy eggs at Bacan hatch between 15 and $24 \mathrm{~h}$ after spawning. Natural mortality $(M)$ of these eggs was estimated on three occasions and averaged $0.15 \pm 0.04 \cdot \mathrm{h}^{1}$. This means that only about $10 \%$ of eggs spawned by anchovies at Bacan survive to hatch.
\end{abstract}

KEYWORDS: anchovies, egg development, age and natural mortality.

\section{INTRODUCTION}

The anchovies (Encrasicholina species: Family Engraulididae) are the most important of the small pelagic fishes used for live-bait in Maluku. These fish are caught at night by "bagans" to sell to the pole-and-line tuna fishing vessels. Three species of anchovy used as baitfish occur in Bacan waters: E. heterolobus, E. devisi and E. punctifer (in small numbers). Some aspects of the reproductive biology of Encrasicholina have been studied in other geographic areas (Tiews et al., 1970; Sumadhiharga, 1995: Milton et al., 1994; Wright, 1992). but there have been no studies in this area of Maluku Province. The present paper is part of a study whose aim was to assess the feasibility of estimating the biomass of anchovies using the Daily Egg Production Method (DEPM). Estimates of biomass are an important first step towards a sustainable management plan for the baitfish resources. In order to estimate such biomass, we first needed information on the time from spawning to hatching, the embryonic stage at which eggs hatch, and then finally egg mortality rates. These values are used in the equation to estimate the biomass of fish and accurate data are important if the biomass is not to be underestimated.

One of the most important parameters needed for the DEPM is an accurate estimate of the number of eggs in the plankton. The high mortality that occurs in these early life stages is one of the main factors affecting estimates of biomass. The objectives of this part of the study were therefore to document the stages of embryonic development of anchovy eggs, and to estimate the age of each stage in order ultimately to determine natural mortality rates.

Very little information was available on the embryonic development of tropical anchovies, but Moser \& Ahlstrom (1985) identified eleven stages of development in the Northern anchovy Engraulis mordax, and showed that the rate of development was temperature-dependent. Lo (1985) used these data to fit a temperature-dependent model of the rate of egg development and to estimate the age of eggs at each development stage.

\section{MATERIALS AND METHODS}

\section{Sampling}

Random plankton tows were collected in September, November 1996 and April, July 1997 from the main spawning grounds within the baitground in Bacan waters. Plankton samples were taken using two plankton nets $\left(0.5 \mathrm{~m}^{2}\right.$ and $\left.0.25 \mathrm{~m}^{2}\right)$ of $500-\mu$ mesh. Tows were taken vertically at various depths $(5,10$ and $20 \mathrm{~m})$ with the majority at $10 \mathrm{~m}$. These plankton samples were preserved in $10 \%$ formalin and taken to the laboratory for analysis.

\footnotetext{
Amben Assessment Institute of Agricultural Technology. J. Chr. Soplanit.

Rumah Tiga. Ambon (97233. Indonesia.

** CSIRO Marine Research. PO Box 120, Cleveland. Qld. 416i3. Australia
} 


\section{Laboratory Analysis}

Eggs of anchovies were identified (using the descriptions in Delsman, 1931), sorted and removed from all plankton tows. For staging, each sample was placed in a Bogorov tray and examined under a low power microscope. Anchovy eggs from each sample were counted and staged according to their degree of embryonic development. We recognised 9 developmental stages based on morphological changes that occur during embryogenesis (modified from Moser \&Ahlstrom, 1985). Eggs were aged by relating the time of sampling to the distribution of the modes of each development stage. The mean time between samples collected with the largest number of early (Stage 1) and late stage eggs (Stage 9) was used to estimate total hatching time. These results compared favourably with the total development time estimated with the temperature-dependent model of Lo (1985). As a further confirmation that the estimated development time was realistic, we used the equation of Longhurst \& Pauly (1987) to relate water tem- perature and egg diameter to estimate total hatching time. All three approaches agreed that the total time for eggs to hatch was approximately $16 \mathrm{~h}$. Having established that eggs took $16 \mathrm{~h}$ to hatch, we then interpolated using the model of Lo (1985) to estimate the age at each of the 9 development stages.

Natural mortality of eggs was assumed to be relatively constant, enabling us to estimate mortality from the exponential decay model (Sparre \& Venema, 1992). We sampled continuously for $36 \mathrm{~h}$ on seven occasions during the study. This enabled us to identify the peak period of hatching and to try and follow a cohort of eggs through to hatching and thus estimate their mortality. Tows were made from a fixed position during the night (usually from an anchored bagan) and then randomly in the spawning area during the daytime. A linear regression was fitted to the logarithm of the number of eggs in each stage against time (in $\mathrm{hrs}$ ). The slope of this regression is an estimate of the egg mortality during that period.

Table 1. A description of the embryological development stages of anchovy eggs and the estimated time since spawning.

\begin{tabular}{|c|c|c|}
\hline $\begin{array}{l}\text { Development } \\
\text { Stage }\end{array}$ & $\begin{array}{l}\text { Estimated age } \\
\text { since spawning }\end{array}$ & Description \\
\hline Stage 1 & 1 hour & $\begin{array}{l}\text { egg is transparent and cell division } \\
\text { has not begun }\end{array}$ \\
\hline Stage 2 & 2 hours & egg has two cells or blastomeres \\
\hline Stage 3 & 4 hours & egg has a segmentation \\
\hline Stage 4 & 6 hours & $\begin{array}{l}\text { egg has two third division with the } \\
\text { embryo starting to develop }\end{array}$ \\
\hline Stage 5 & 7.5 hours & $\begin{array}{l}\text { head can be identified but the } \\
\text { structure is not clearly defined }\end{array}$ \\
\hline Stage 6 & 9 hours & $\begin{array}{l}\text { head is clearly defined and vertebrae } \\
\text { can be seen in the middle of the egg }\end{array}$ \\
\hline Stage 7 & 11 hours & $\begin{array}{l}\text { head, vertebrae and tail make up } \\
\text { more than half of the egg }\end{array}$ \\
\hline Stage 8 & 12.5 hours & $\begin{array}{l}\text { the tail begins to separate from the } \\
\text { yolk }\end{array}$ \\
\hline Stage 9 & 15 hours & $\begin{array}{l}\text { the tail is clearly seen and the yolk } \\
\text { has begun to be resorbed }\end{array}$ \\
\hline
\end{tabular}




\section{RESULTS AND DISCUSSION}

Most plankton samples contained eggs in several stages of development. This means that anchovies do not spawn their eggs at the same time. The stages of embryonic development were simi. lar to those identified for Engraulis mordax (Moser $\&$ Ahlstrom, 1985). The stages and the estimated age are described in Table 1 and shown in Figures 1 to 3 . The data suggest that anchovy eggs hatch after at least $16 \mathrm{~h}$. This result is also confirmed when the relationship between mean egg diameter and water temperature is calculated (Longhurst $\&$ Pauly. 1987). The estimated mean time to hatching using this equation was also $16 \mathrm{~h}$.

The 36 -h plankton sampling did not show any clear pattern of reducing egg abundance with time on four of the seven days. However, the plankton data on the other three days (13 April, 14 and 16 July 1997) could be used to estimate mortality for some of the older age classes. The mean estimated mortality $(M)$ was $0.15 \pm 0.04$ h $^{1}$ for those three days (Figure 4). The mortality estimates for each day varied from $0.14 \pm 0.03$ to $0.17 \pm 0.05 . \mathrm{h}^{-1}$. This equated to a mean mortality of approximately $90 \%$ over the $16 \mathrm{~h}$ from spawning to hatching. These values are much higher than those estimated for more temperate species. Koslow \& Bulman (1997) estimated egg mortality to be about $5 \%$.d ' for Blue
Grenadier Macruronus novaezelandiae off southern Tasmania and Fletcher et al. (1996) found values between 0.43 to $0.81 . \mathrm{d}^{1}$ for the sardine Sardinops sagax in Western Australia.

Anchovies have adapted to the high, and probably variable, mortality rates of eggs and larvae by spawning frequent, small batches of eggs (Andamari \& Milton, this issue). Both $E$. heterolobus and $E$. devisi have higher lifetime egg production in Bacan than in the Pacific (Solomon Islands) which may be an adaptation to high egg mortality. We tried to separate the anchovy eggs in the plankton into different species according to Delsman (1931) and almost all were of the $E$. heterolobus form. Given that E. heterolobus is also the dominant species in adult catches and their higher egg production (Andamari \& Milton, this issue), our mortality estimates are probably specific to this species.

\section{Acknowledgments}

We thank to Ms. Pradina Hatta for assistance in taking the photographs and $\mathrm{Mr} \mathrm{T}$. Zubaidi for scanning the pictures. This work formed part of the Indonesia-Australia Baitfish Research Project in eastern Indonesia funded by the Australian Centre for International Agricultural Research (P/ N 9424).

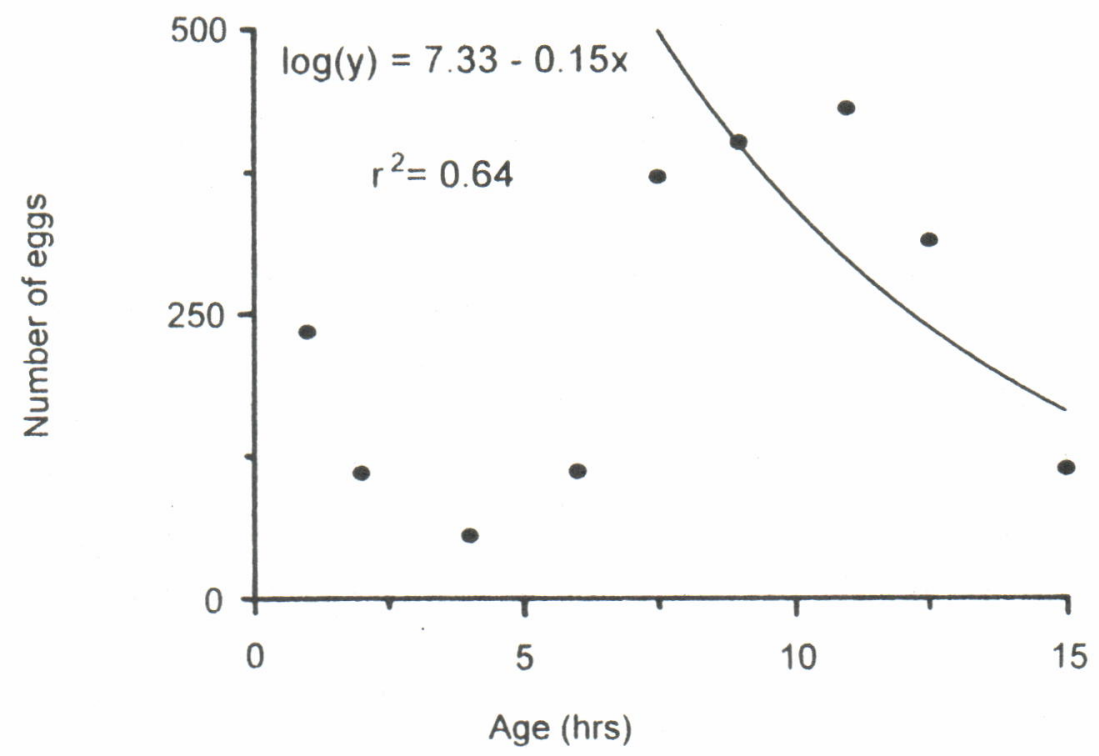

Figure 1. The first four stages of anchovy embryo development and their approximate ages. 


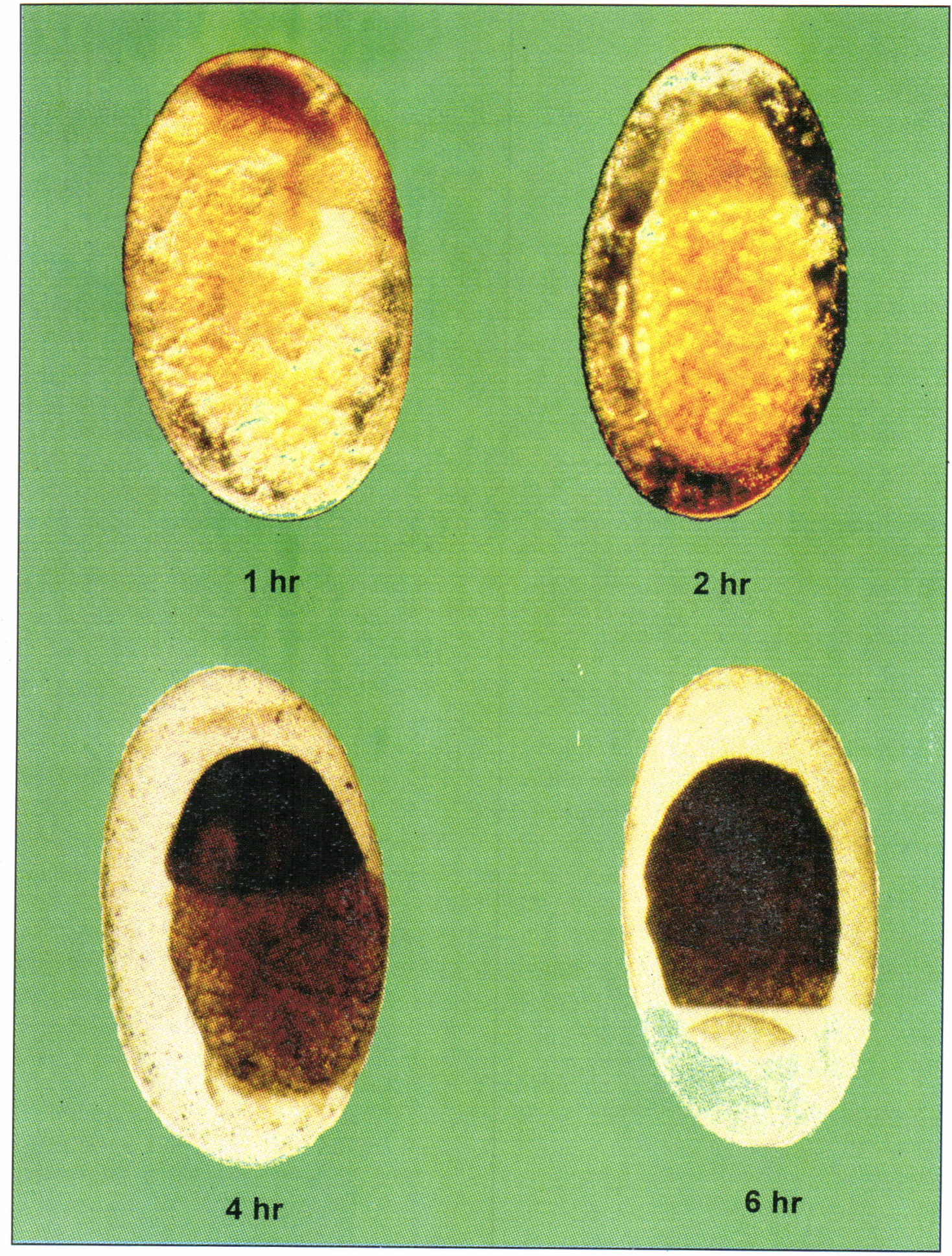

Figure 2. The first four stages of anchovy embryo development and their approximate ages. 


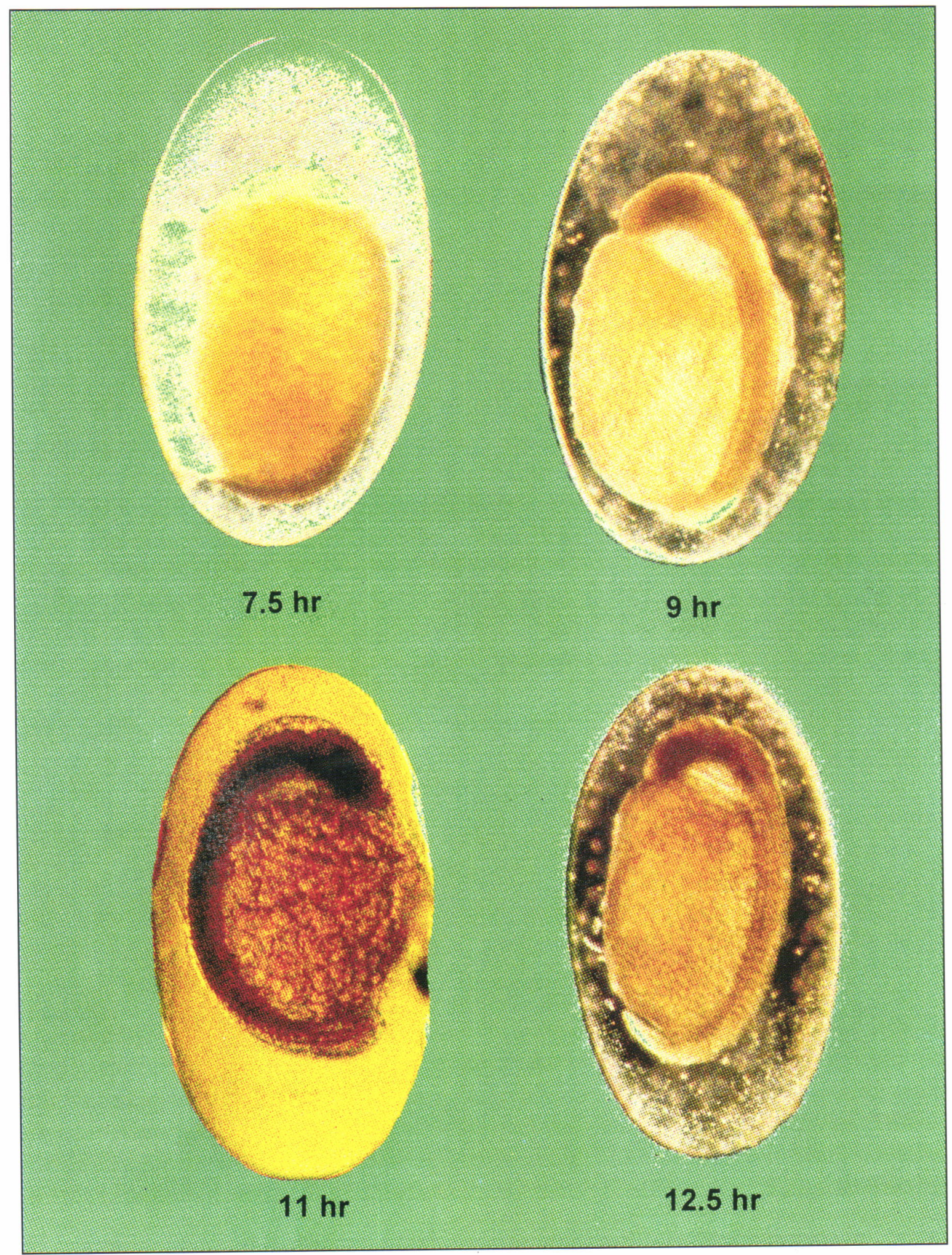

Figure 3. The mid-stages of anchovy embryo development showing the early larvae. 


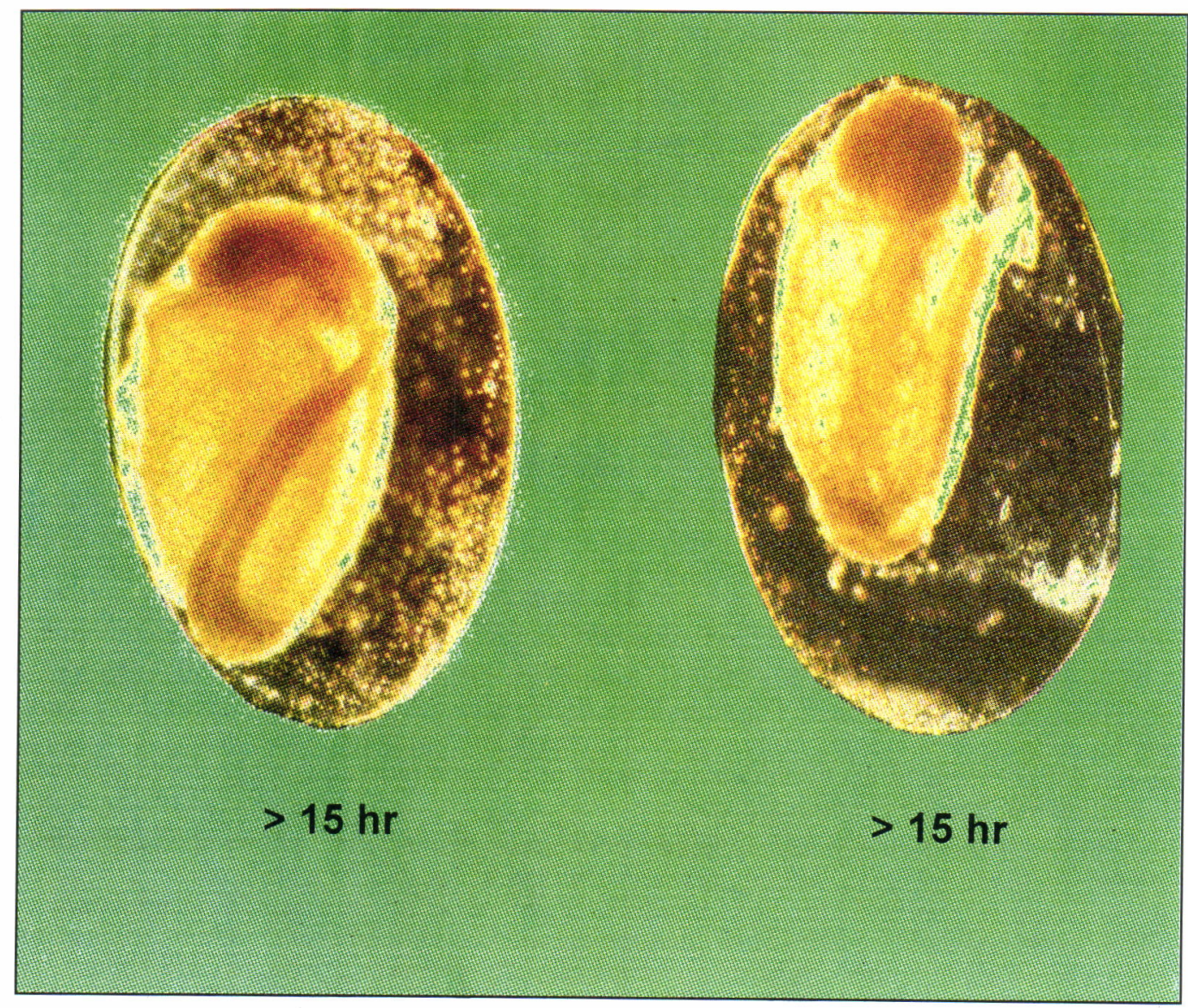

Figure 4. Late stage anchovy larval development just prior to hatching.

\section{REFERENCES}

Delsman, H.C. 1931. Fish eggs and larvae from the Java Sea. The genus Engraulis. Treubia 13: 217-243.

Fletcher, W.J., Lo, N.C.H., Hayes, E.A., Tegonning, R.J. and Blight, S.J. 1996. Use of the daily egg production method to estimate the stock size of western Australian sardines (Sardinops sagax). Mar. Fresh. water Res. 47: 819-25.

Koslow, A. and Bulman, C. 1997. Development of the egg production method to assess the blue grenadier stock in the southeast fishery. FRDC Final Rep. 95/035, Canberra, Australia.

Longhurst A.R. and Pauly, D. 1987. Ecology of Tropical Oceans. Academic Press, California. 389 pp.

Lo, N.C.H. 1985. A model for temperature dependent northern anchovy egg development and an auto. mated procedure for the assignment of age to staged eggs, In Lasker, R. (ed.). An Egg Production Method for Estimating Spawning Biomass of Pelagic Fish: Application to the Northern Anchovy, Engraulis mordax. NOAA Tech. Rep. NMFS 36: 43-50.
Milton, D.A., Blaber, S.J.M and Rawlinson, N.J.F. 1994. Reproductive biology and egg production of three species of Clupeidae from Kiribati, tropical central Pacific. Fish. Bull. U.S. 92: 102-121.

Moser, H.G. and Ahlstrom, E.H. 1985. Staging anchovy eggs. In Lasker, R. (ed.). An Egg Production Method for Estimating Spawning Biomass of Pelagic Fish: Application to the Northern Anchovy, Engraulis mordax. NOAA Tech. Rep. NMFS 36: 37-41.

Sumadhiharga, O.K. 1995. Anchovy Fisheries and Ecology with Special Reference to the Reproductive Biol. ogy of Stolephorus Species in Ambon Bay, Indonesia. PhD Thesis. University of Tokyo, Japan. 143 pp.

Tiews, K., Ronquilo, L.A. and Santos, L.M. 1970. On the biology of anchovies (Stolephorus Lacépčde) in Philippine waters. Proceedings of the Indo-Pacific Fish. Council 13(II): 20-48.

Wright, P.J. 1992. Ovarian development, spawning frequency and batch fecundity in Encrasicholina heteroloba (Rüppell, 1958). J. Fish. Biol. 40:833844. 